\title{
PATHOGENICITY OF THE FUNGUS, BEAUVERIA BASSIANA TO THE RED PALM WEEVIL, RHYNCHOPHORUS FERRUGINEUS UNDER FIELD CONDITIONS
}

\author{
BEKHIET H. K. ${ }^{1}$, M. A. ALI ${ }^{1 *}$, D. A. RAGHEB ${ }^{2}$ and A. A. EL-FESHAWAY ${ }^{2}$ \\ 1. Plant Prot. Inst., ARC., Dokki, Giza, Egypt \\ 2. Plant Prot. Dept., Fac. Agric., Zagazig Univ., Egypt \\ * Corresponding author: Tel. : +201065053461 \\ E-mail address: abdelsalam_eg@yahoo.com
}

(Manuscript received 28 August 2017)

\begin{abstract}
$\mathrm{T}$ he present study was carried out at El-Kassasin district Ismailia Governorate, Egypt to evaluate the virulence of entomopathogenic fungus, Beauveria bassiana against of the red palm weevil under field conditions. Field trials showed that the injection of $B$. bassiana-9894 in infested palm trees gave successful recovery at light and median infestation level. On the other hand, dusting a date palm trees with $B$. bassiana-9894 caused an increase in adult weevil infestation and reduction of the palm trees infestation. The obtained results also showed that the chemical insecticides Chlorzan 48\% EC and Diazinox 60\% EC were highly effective against red palm weevil.

Key words: Rhynchophorus ferrugineus, microbial control, entomopathogenic fungus, Beauveria bassiana.
\end{abstract}

\section{INTRODUCTION}

The red palm weevil, Rhynchophorus ferrugineus (Olivier) belongs to the family of Curculionidae (Coleoptera). $R$. ferrugineus is a major economic pest of coconut palm, date palm, oil palm and sago palm. Nowadays, $R$. ferrugineus is known as the most destructive pest to date, coconut and oil palms in Arabic region and south East Asia (Hanounik, 1998). It has been known first in south east Asia until it appeared in United Arab Emirates in 1985, Kingdom of Saudi Arabic in 1987 (Murphy and Briscoe, 1999) and Egypt in 1992 (Saleh, 1992).

The use of biological control agents in the management of insect pests has increased in recent years. Due to the deep concerns about environmental pollution and health risks associated with use of chemical insecticides. Among biological control measures are the entomopathogenic fungi which are considered potentially and environmentally safe to invertebrates and plant species in addition to their wide use in control of many insect pests ( Chakaravarthy et al., 2008).

$R$. ferrugineus has been found naturally infected by the entomopathogenic fungus, Beauveria bassiana (Berenice et al., 2010). B. bassiana is known as an entomopathogenic fungus with a worldwide distribution and abroad spectrum 
insecticidal activity (Martin et al., 2000). This fungus has proven to be effective for the control of many Coleopteran species, (Magra et al., 2004). Gindin et al., (2006) and El-Sufty et al., (2007) who recommended using the fungi in the management programs of $R$. ferrugineus.

\section{MATERIALS AND METHODS}

\section{Beauveria bassiana.}

The strain of $B$. bassiana used in this study was isolated from infected cadaver adults of $R$. ferrugineus collected from El-Kassasin area. Isolated fungi were purified and identified in Assuit University Mycological Center (AUMC).

The fungus conidia were cultured on agar Petri dishes of Dox medium (Thom and Raper., 1945). B. bassiana-9894 aerial conidia were mass produced using biophasic culture system (Sewify et al., 2009).

\section{Chemical insecticides.}

Two insecticides recommended for the red palm weevil by the Ministry of Agriculture in Egypt were tested.

\section{A: Diazinox 60\% EC (Diazinon).}<smiles>CCOP(=S)(OCC)Oc1cc(C)nc(CC)n1</smiles>

Chemical name: O,O-diethyl O-[6-methyl-2-(1-methylethyl)-4-pyrimidinyl] phosphorothioate.

\section{B: Chlorzan $48 \%$ EC ( Chlorpyrifos).}<smiles>CCOC(=S)c1nc(Cl)c(Cl)cc1Cl</smiles>

Chemical name: 0,0 -diethyl 0 -(3,5,6-trichloro-2-pyridinyl) phosphorothioate.

3. Evaluating the efficiency of the effectiveness of $B$. bassiana-9894 against the red palm weevil, $R$. ferrugineus in the field.

Field applications were conducted on 17 Fadden's containing 1134 date palm, $P$. dactylifera. The field plantation included naturally RPW infested and non-infested palm trees ranging in age between $7-12$ years $(5 \times 6 \mathrm{~m}$ between palms) at El-Kassasin area, Ismailia Governorate, Egypt. Infested date palms were marked at the start of the experiments. 


\subsection{Injection of fungus, $B$. bassiana-9894 suspension in palm trees.}

A stock solution of the fungal formulation was prepared $(2 \mathrm{~g} \mathrm{~B}$. bassiana-9894 spores suspended in $100 \mathrm{ml}$ sunflower oil and $0.02 \%$ Tween-80 and then sterilized distilled water was added to make 1liter and well mixed). The conidia concentration $\left(10^{8}\right.$ spores $\left./ \mathrm{ml}\right)$ in the resulting suspension was determined by the use of a haemocytometer slide and adjusted to the desired concentration.

Thirty five naturally infested palm trees with $R$. ferrugineus (5-9 years old) were treated with $B$. bassiana-9894 spore's suspension formulated in sunflower oil according to (Sewify et al., 2009). These infested palm trees were divided into three levels, light, median and heavy level of infestations. Fungal spores at concentration of $10^{8} \mathrm{spores} / \mathrm{ml}$ formulated in emulsified sunflower oil in $0.02 \%$ Tween-80 at concentration of $1.0 \mathrm{ml} / \mathrm{L}$ was injected through PVC tubes $(30 \mathrm{~cm}$ long and $16 \mathrm{~mm}$ diameter) inserted in deep holes $(20 \mathrm{~cm})$ made at $45^{\circ} \mathrm{C}$ angel into the core of an infected palm near the top of the insect infestation level ( 2 liter/palm). These holes were made with a $50 \mathrm{~cm}$ long and $16 \mathrm{~mm}$ thick screw. Numbers of inserted tubes depended on infestation level. The application was repeated on weekly bases for two consecutive weeks. The numbers of dry and wet galleries were recorded. Evidence of recovery tree was determined by external signs which were the absence of fresh sap liquid appearing externally on the tree trunk as well as the absence of the bad pungent smell. Also, a thin twig was inserted in the bored holes to verify the dryness of fluid in the inner tissues.

\subsection{Dusting of $B$. bassiana-9894.}

Field applications by dusting the formulated fungus, B. bassiana-9894 spores, at concentration of $10^{8}$ spores /g (Sewify et al., 2009) were carried out on red palm weevil-infested trees starting from March 2012 up to May 2013. Formulated spores were dusted before evening on leaf axils and palm trunks $(80 \mathrm{gm} / \mathrm{palm})$ by using motorized Knapsack sprayer (Agrimondo HP 5). Control palms were left untreated. The $B$. bassiana-9894 formulation was applied 4 times throughout the year (starting in March 2012) at approximately 3- month intervals. Efficacy of treatments was based on monthly mortalities caused by the fungus in RPW adult population. Therefore, adults were weekly collected by pheromone traps a month before application and continued till May 2013. For each sample, cadavers of dead weevils were disinfected by immersing in $1 \%$ sodium hypochlorite for 15 seconds, washed in sterile water and exposed to mycosis test. The cadavers were placed on moistened filter papers inside Petri dishes. The dishes were incubated at $25 \pm 2{ }^{\circ} \mathrm{C}$ and $60-70 \%$ R.H for 10 days and 
the fungus growth was observed. The cadavers that showed external growth of the fungus were considered killed by the fungus.

\section{Effect of Diazinox $60 \%$ and Chlorzan $48 \%$ EC on the red palm weevil.}

The experiment was carried out to test the efficacy of two insecticides (Diazinox $60 \%$ and Chlorzan $48 \%$ EC) for control of RPW on date palm trees. Sixty infested date palm trees were selected to control using the two insecticides. Date palm orchard was visited thoroughly and all the trees which were being damaged by RPW were identified, marked and tagged. From infested palms a brown fluid was oozing out from the minute holes made by RPW. Three to seven holes were made above the insect attacking point. The holes were drilled at $45^{\circ}$ angle downwards the infestation points.

The insecticides were diluted in distilled water (Diazinox $60 \% \mathrm{EC} 3 \mathrm{~cm} / \mathrm{l}$ and Chlorzan $48 \% \mathrm{EC} 3 \mathrm{~cm} / \mathrm{l}$ ) before application to the trees and 2 liter per tree of diluted insecticide was injected in the holes. All the trees were observed at 7 and 21 days and thoroughly checked that the oozing has stopped or till loosening.

\section{Analysis of results.}

Experimental data were analyzed using one way analysis of variance (ANOVA) using SPSS (statistical package for social sciences, ver. 20), and the significance among the samples was compared at $P \leq 0.05$. Results were represented as mean $\pm S E$ $(n=4)$.

\section{RESULTS AND DISCUSSION}

\section{Evaluating the efficiency of $B$. bassiana-9894 against red palm weevil, $R$.} ferrugineus in the Filed.

\subsection{Effect of $B$. bassiana-9894 application by trunk injection method.}

Data in Table(1) and Fig.(1\&2), show the treatment of red palm weevil, $R$. ferrugineus in infested palms with spores of fungus, B. bassiana-9894 at a concentration of $3 \times 10^{8}$ spores $/ \mathrm{ml}$ formulated in sunflower oil $(0.1 \mathrm{ml} / \mathrm{l})$ through injection method. Three different levels of infestation were considered, light, median and heavy infestation as depicted by visible external symptoms. As shown in Table (1) Fig. (1), the light infestation level showed a high response to treatment with the fungal spores followed by median and heavy infestations. The light level infestation showed recovery from infestation after one week from the injection of the fungus, $B$. bassiana-9894 formulation in drilled holes in the tree trunks. The percent of dry galleries was $81.8,58.82$ and $0.0 \%$, as a result of fugal injection in light, median and heavy infested palm, after one week post-treatment, respectively. 
Therefore, in the second week, a second fungus formulation was administered by injection through the fitted perforated rubber tubes only in the tree that still exhibiting symptoms of infestation.

The treatments gave 100, 76.47 and $0.0 \%$ successful cure two weeks posttreatment for the three levels of infestation, respectively. Subsequently, after the third week from initial application of B. bassiana-9894, results were $100,88.23$ and $0.00 \%$ recovery at the three levels of infestation, respectively.

Data in Table (1) and Fig. (1) cleared that the heavily infested palm trees showed no external sign of recovery from infestation. Therefore, the heavily infested palm trees negatively responded with fugal treatment compared to the light and median infestation.

Table 1. Efficiency of $B$. bassiana-9894 $\left(10^{8}\right.$ spores $\left./ \mathrm{ml}\right)$ against three levels of infestation by $R$. ferrugineus on date palm trees applied by trunk injection method.

\begin{tabular}{|c|c|c|c|c|}
\hline \multirow{2}{*}{$\begin{array}{c}\text { Type of } \\
\text { infestation }\end{array}$} & \multirow{2}{*}{$\begin{array}{l}\text { Number of } \\
\text { treated palm }\end{array}$} & \multicolumn{3}{|c|}{$\%$ Recovry after treatment } \\
\hline & & One week & Two weeks & Three weeks \\
\hline Light & 11 & 81.8 & 100 & 100 \\
\hline Median & 17 & 58.82 & 76.47 & 88.23 \\
\hline Heavy & 7 & 0.00 & 0.00 & 0.00 \\
\hline \multicolumn{2}{|c|}{ Mean recovery of infestation } & $54.29 \%$ & $68.57 \%$ & $74.29 \%$ \\
\hline \multicolumn{2}{|c|}{$\begin{array}{l}\text { General average of recovered } \\
\text { infestation }\end{array}$} & \multicolumn{3}{|c|}{$65.72 \%$} \\
\hline
\end{tabular}

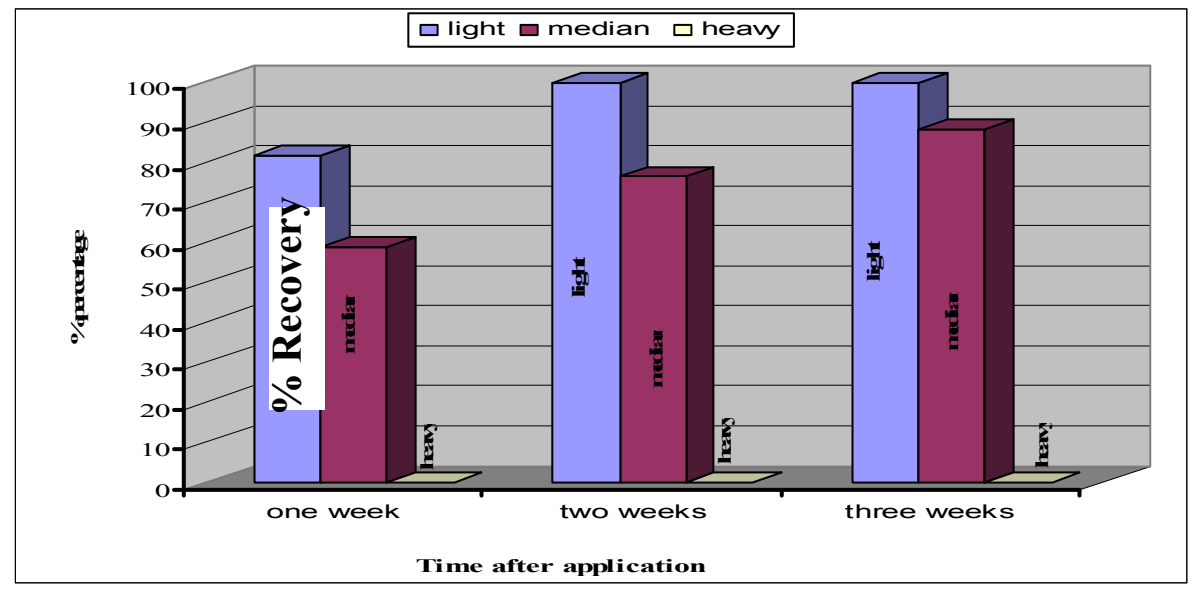

Fig. 1. Percentage of recovered date palms from infestation by the red palm weevil, $R$. ferrugineus after injection with the fungus, B. bassiana-9894.

It could be concluded from the obtained results of the present field application that treatment with the fungus, $B$. bassiana-9894 by trunk injection in tree in three different categories of infestation caused $54.29 \%$ average recovery after one week (Table, 1 and Fig., 2). 
Meanwhile, the percent of recovered date palm trees from infestation by the red palm weevil after trunk injection with the fungus was $68.57 \%$ and $74.29 \%$ after two and three weeks when treated for the $2^{\text {nd }}$ and $3 \mathrm{~d}$ time, respectively.

Therefore, general average of recovered infestation after trunk injection with B. bassiana was $65.75 \%$ (Table, 1 and Fig., 2).

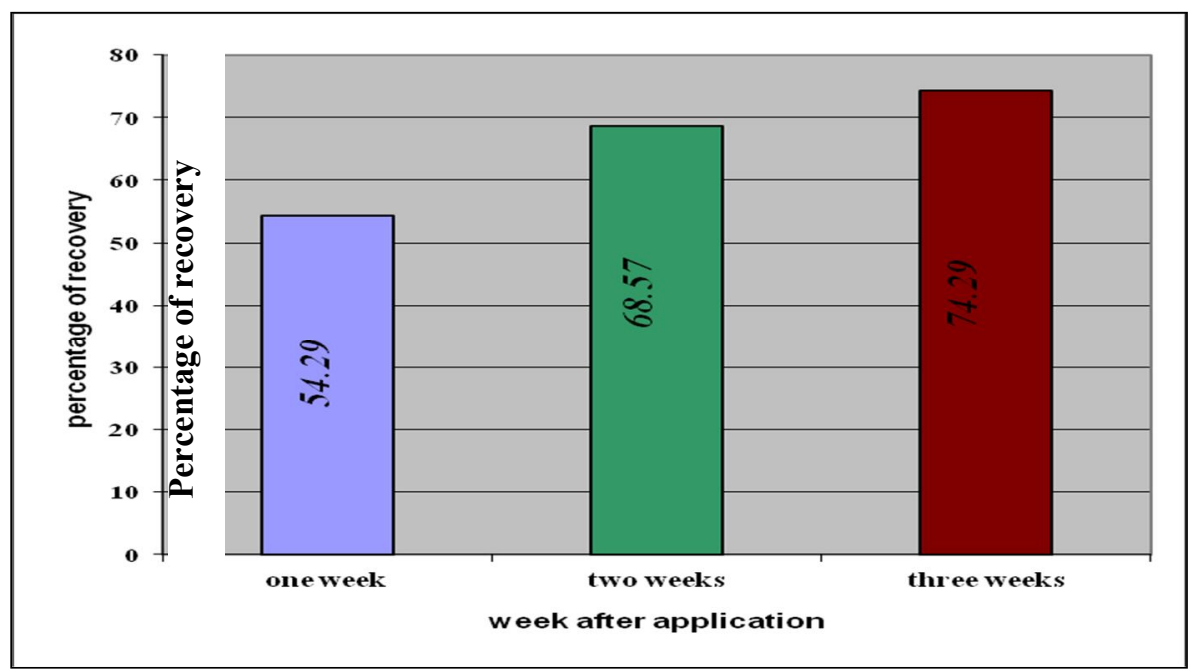

Fig. 2. Mean percentage of recovery date palm trees from infestation by red palm weevil after injection with $B$. bassiana-9894.

According to Yasuda et al., (2000) and Consolo et al. (2003) the efficiency of $B$. bassiana formulation for controlling many insect species was enhanced when prepared in a corn oil formulation.

Our results agree with Sewify and Fouad (2006) who mentioned that $B$. bassiana in combination with mint oil at low concentration injected into palm trees was an effective method for controlling $R$. ferrugineus within two weeks, but the satisfying control varied according to infestation levels.

\subsection{Effect of $B$. bassiana application by dusting method.}

Data in Table (2) and illustrated in Fig. (3) revealed that dusting fungus, $B$. bassiana-9894 $\left(10^{8}\right.$ spores $\left./ \mathrm{ml}\right)$ in treated area increased the numbers of fungal infected weevils captured by terrestrial food baited aggregation pheromone trap, compared with untreated area.

Captured red palm weevils by traps were scored as dead or alive and whenever present insects with signs of mycoses were also scored. Palm trees infestation by red palm weevil was scored. The red palm weevil population was larger in untreated palms area than in treated palms area. The largest number of living adults was found in untreated palms area, unlike treated ones. Reduction of red palm 
weevil, $R$. ferrugineus in treated palms area could be due to the action of the entomopathogenic fungus, B. bassiana-9894.

Table 2. Infection of red palm weevil, $R$. ferrugineus captured by traps from untreated and treated areas with B. bassiana-9894 through 2012 - 2013 applied by dusting method.

\begin{tabular}{|c|c|c|c|c|c|c|c|}
\hline & \multicolumn{5}{|c|}{ Months of dusting } & \multirow{2}{*}{ Mean } & \multirow{2}{*}{ Interaction } \\
\hline & March & June & September & December & March & & \\
\hline Untreated & 0.81 & 1.28 & 0.00 & 0.00 & 1.54 & $0.726^{\mathrm{b}}$ & \multirow{3}{*}{$* *$} \\
\hline Treated & 8.71 & 26.96 & 37.30 & 45.85 & 67.58 & $37.28^{\mathrm{a}}$ & \\
\hline Mean & $4.76^{c}$ & $14.12^{\mathrm{b}}$ & $18.65^{\mathrm{ab}}$ & $22.925^{\mathrm{ab}}$ & $34.56^{a}$ & & \\
\hline
\end{tabular}

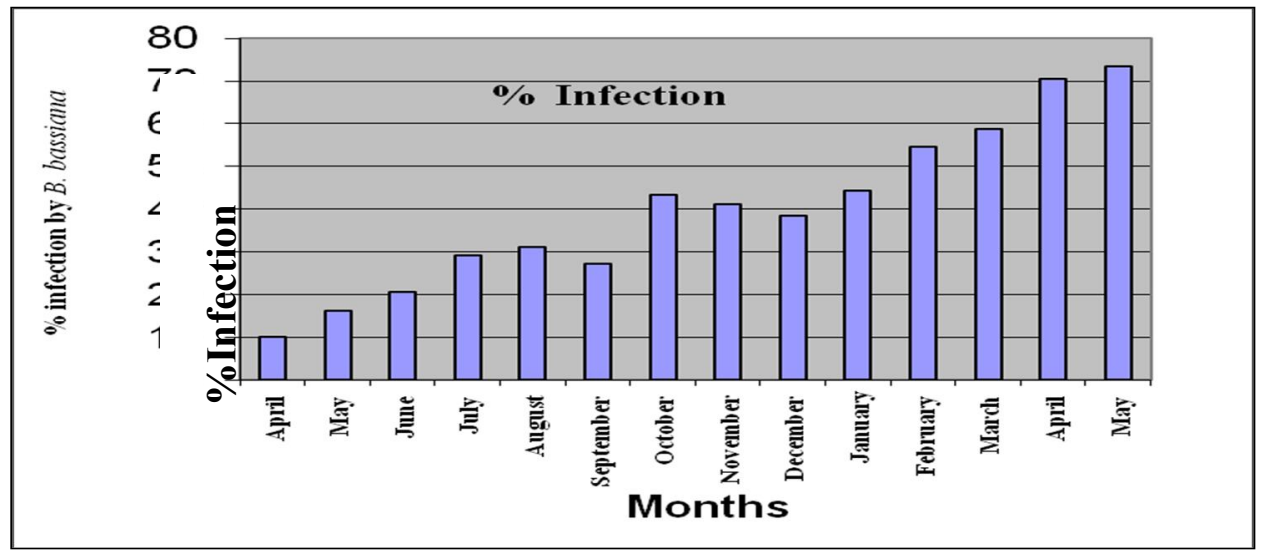

Fig. 3. Percentages of fungal-infected adults of red palm weevil by captured traps as a result of application of $B$. bassiana-9894 (2012-2013).

Three months after the first field application of B. bassiana-9894 formulation, the percentage of fungal infected weevils was 10, 16.12\% in April and May (2012), respectively. In control area, the recorded fungal infected adults were zero, $2.4 \%$ in April and May (2012), respectively. The percentage of the fungal infected weevils after 6 months of B. bassiana-9894 treatments increased to 31.03\%, in August (2012). This could be due to the large RPW infestation prior to our $B$. bassiana-9894 treatments.

Subsequently, at least one application of the fungus, B. bassiana-9894 increased the percentage of trapped fungal infected weevil in treated area to 70.59, 73.33\% in April and May (2013), respectively. This would maintain a B. bassiana-9894 treatments reduce the impact of red palm weevil infestation, such as in this study.

Data in Table (3) and illustrated data in Fig. 4 show that the induced reduction of captured weevils was due to the application of the fungus, $B$. bassiana9894 in May (2012) recording 13.77\%, then enhanced to reach $57.69 \%$. Reduction rate of captured weevils of red palm increased to $71.48 \%$ in May 2013. 
On the other hand, results in Table (3) and illustrated in Fig. (5) indicat a reduction of infested palm trees in area treated with the entomopathogenic fungus, $B$. bassiana-9894 in comparison with untreated area. Data in Table (3) revealed that the numbers of infested palm trees decreased during 2013 when compared with 2012. Data in Table (3) reveal a reduction rate of infested palm trees reached $21.33 \%$ and 45.58\% in May and August 2012, respectively. The reduction rate increased to reach it 66.54\% in May 2013.

Table 3. \% Infection, reduction of the captured weevils and \% reduction of infested palm trees as a result of application of B. bassiana-9894 (2012-2013).

\begin{tabular}{|c|c|c|c|}
\hline Months & $\begin{array}{c}\text { \% Infection of red } \\
\text { palm weevil }\end{array}$ & $\begin{array}{c}\text { \%Reduction in captured } \\
\text { weevils }\end{array}$ & $\begin{array}{c}\text { \% Reduction of infested } \\
\text { palm trees }\end{array}$ \\
\hline March & 0 & 9.93 & 0 \\
\hline April & 10 & 12.39 & 21.33 \\
\hline May & 16.12 & 13.77 & 35.24 \\
\hline June & 20.68 & 29.77 & 41.39 \\
\hline July & 29.19 & 44.84 & 45.58 \\
\hline August & 31.03 & 36.48 & 42.86 \\
\hline September & 27.27 & 47.80 & 46.03 \\
\hline October & 43.47 & 52.37 & 50.84 \\
\hline November & 41.17 & 61.12 & 49.21 \\
\hline December & 38.46 & 57.69 & 49.40 \\
\hline January & 44.44 & 65.58 & 55.18 \\
\hline February & 54.54 & 72.16 & 60.32 \\
\hline March & 58.82 & 67.18 & 61.90 \\
\hline April & 70.59 & 69.74 & 66.54 \\
\hline May & 73.33 & 71.48 & \\
\hline
\end{tabular}

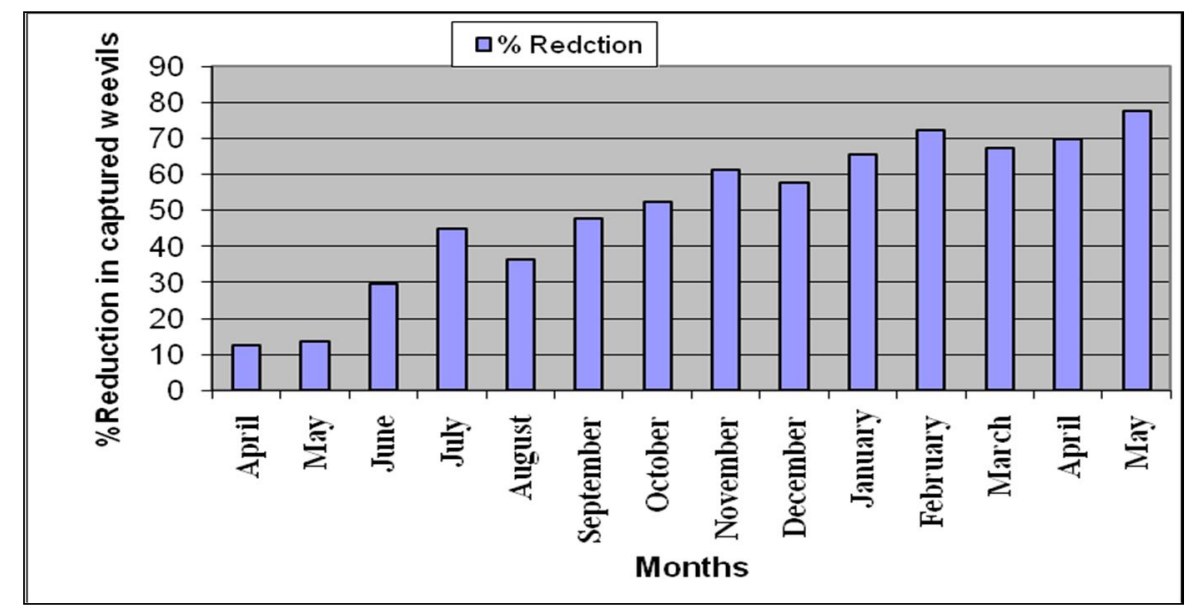

Fig. 4. Effect of $B$. bassiana -9894 application on reduction rate of red palm weevil captured by traps (2012-2013). 


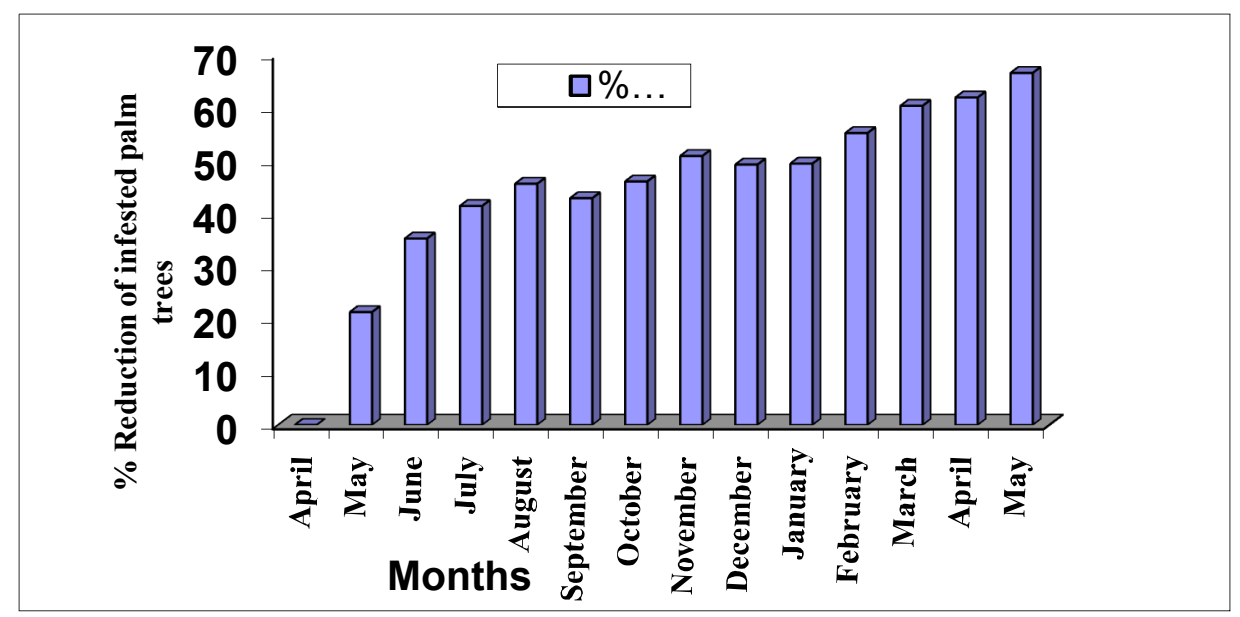

Fig. 5. Effect of $B$. bassiana-9894 application on reduction rate of infested palm trees with red palm weevil, R. ferrugineus (2012-2013).

This result agree with El-Sufty et al., (2007) and Sewify et al., (2009) who concluded that the dusting application increased fungal infected weevil captured by traps. Sewify et al., (2009) reported also that the fungal dusting application increased fungal infected weevil captured by traps. They stated that the increment in the percentage of fungal infected weevil was occurred in the second year of fungal application. The authors noticed, in field observation, that in most cases, adult weevils didn't fly directly from palm to another but they droped on ground then, walked and hid behind the target palm frond axils. Mueller-Koegler (1965) stated that the high population density of host insect enhances the development of the fungus disease in the population. The delayed effect of the fungus may be attributed to the development and sporulation of the fungus on cadavers of infected weevils, thereby spreading the fungus inoculums in the population. The results showed that our $B$. bassiana cause RPW mortality, and reduced RPW populations and palm infestation levels. El-Sufty et al., (2011) mentioned that the adult weevils themselves act as very efficient carriers of the fungus conidia.

These results suggest that fungus $B$. bassiana-9894 is a promising agent for use as biological control agent to control the red palm weevil, $R$. ferrugineus.

\section{Field evaluations of the chemical insecticides by trunk injection of palm} trees.

The effectiveness of two pesticides (Chlorzan 48\% EC and Diazinox 60\%EC) on red palm weevil, $R$. ferrugineus was assessed after one week to three weeks from treatment under field conditions and the obtained results were tabulated in Table(4).

The results indicated that the chemical insecticides were more effective on red palm weevil than the tested bioagents. The results in Table (4) showed that Chlorzan $48 \% \mathrm{EC}$ was the most efficient treatment to control red palm weevil infestation, as the 
recovery reached 100,100 and $83.33 \%$ at light, median and heavy infestation date palm trees, respectively after one week.

Table 4. Efficiency of chemical insecticides against three levels of $R$. ferrugineus infestation on date palm trees applied by injection method.

\begin{tabular}{|c|c|c|c|c|c|}
\hline \multirow{2}{*}{ treatments } & \multirow{2}{*}{$\begin{array}{c}\text { Type of } \\
\text { infestation }\end{array}$} & \multirow{2}{*}{$\begin{array}{l}\text { Number of } \\
\text { treated palms }\end{array}$} & \multicolumn{3}{|c|}{$\%$ of palm recovery after treatment } \\
\hline & & & One week & Two weeks & Three weeks \\
\hline \multirow{5}{*}{$\begin{array}{c}\text { Chlorzan } \\
48 \% E C \\
(3 \mathrm{~cm} / \mathrm{l})\end{array}$} & Light & 15 & 100 & 100 & 100 \\
\hline & Median & 11 & 100 & 100 & 100 \\
\hline & Heavy & 6 & 83.33 & 100 & 100 \\
\hline & \multicolumn{2}{|c|}{ Recovery infestation } & $96.88 \%$ & $100 \%$ & $100 \%$ \\
\hline & \multicolumn{2}{|c|}{$\begin{array}{c}\text { General average of recovered } \\
\text { infestation }\end{array}$} & \multicolumn{3}{|c|}{$98.96 \%$} \\
\hline \multirow{5}{*}{$\begin{array}{c}\text { Diazinox } 60 \% \mathrm{EC} \\
(3 \mathrm{~cm} / \mathrm{l})\end{array}$} & Light & 12 & 100 & 100 & 100 \\
\hline & Median & 9 & 100 & 100 & 100 \\
\hline & Heavy & 7 & 71.43 & 100 & 100 \\
\hline & \multicolumn{2}{|c|}{ Recovery infestation } & $92.86 \%$ & $100 \%$ & $100 \%$ \\
\hline & \multicolumn{2}{|c|}{$\begin{array}{c}\text { General average of recovered } \\
\text { infestation }\end{array}$} & \multicolumn{3}{|c|}{$97.62 \%$} \\
\hline
\end{tabular}

On the other hand, Diaznox $60 \% \mathrm{EC}$ caused 100,100 and $71.43 \%$ recovery at the same levels after one week. Percentages of recovery of palm trees at the three levels of infestation showed $100 \%$ two weeks post-treatment with the two tested insecticides.

It could be concluded that the successful treatment of infested palm trees was achieved by using injection of a formulation of B. bassiana-9894 in combination with sunflower oil at the concentration $3 \times 10^{8}$ spores $/ \mathrm{ml}$. The successful was observed in suppressing infestation by the red palm weevil in light and median infested trees as depicted by external symptoms of infestation on the trunk of date palm trees. However, when the fungus formulation was injected at the same concentration in heavy infested trees it had no effect as signs of infestation were even more evident.

Field observation proved that the fungal dusting application increased fungal infected weevil captured by traps in treated area when compared with untreated area. An increase in percentage of fungal infected weevil occurred in the second year of fungal application. Dusting fungus reduced the population of red palm weevil in treated area compared with untreated area. Reduction of red palm weevil, $R$. ferrugineus in treated palms area could be due to the action of the entomopathogenic fungus, B. bassiana-9894.

The results indicated that the chemical insecticides (Chlorzan $48 \%$ EC and Diazinox $60 \% \mathrm{EC}$ ) were more effective on red palm weevil than the tested bio-agents. 


\section{REFERENCES}

1. Berenice, E.; Sonia. G.; Leticia, A.; Pablo, B. and V. Luis. 2010. Infection of the red palm weevil (Rhynchophorus ferrugineus) by the entomopathogenic fungus, Beauveria bassiana A SEM study. Microscopy Res. and Techn. 73: 714-725.

2. Chakaravarthy, A. K.; N. R. Prasanna Kumar and L. V. Kumar. 2008. Bio-efficacy of GB (Garlic Barrier) on insect pests of Gherkins (Cucumis sativus L., Family; Cucubitacae). Pestol., 32(9): 33-36.

3. Consolo,V. F.: G. L. Salerno and C.M. Beron. 2003. Pathogenicity, formulation and storage of insect pathogenic hyphomycetous fungi tested against Diabrotica speciosa. Biocontrol, 48: 705-712.

4. EL-Sufty, R.; S. AL-Bgham; S. AL-Awash; A. Shahdad and A. AL-Bathra. 2011. A trap for auto-dissemination of the entomopathogenic fungus Beauveria bassiana by red palm weevil adults in date palm plantations. Egyptian J. Biol. Pest Control, 21(2): 271-276.

5. El-Sufty, R; S. A. Al-Awash; A. M. Al-Amiri ; A. S. Shahdad ; A. H. Al-Bathra and S. A. Musa. 2007. Biological control of red palm weevil, Rhynchophorus ferrugineus (Col.:Curculionidae) by the entomopathogenic fungus Beauveria bassiana in United Arab Emirates. Acta-Horticulturae. (736): 399-404.

6. Gindin, G; S. Levski; I. Glazer and V. Soroker. 2006. Evaluation of the entomopathogenic fungi Metarhizium anisopliae and Beauveria bassiana against the red palm weevil Rhynchophorus ferrugineus. Phytoparasitica-. 34(4): 370-379.

7. Hanounik, S. B. 1998. Steinernematides and Heterorhabditides as biological control agents for the red palm weevils (Rhynchophorus ferrugineus) Sultan Qabus Univ. J. Sci. Res., Agric. Sci., 3:95-102.

8. Magra, E.; C. M. Nankinga; C. S. Gold; S. Kyammanya; P. Ragama; W. K. Tushemeirwe; D. S. M. Moore and S. R. Gowen. 2004. Efficacy of Beauveria bassiana substrates and formulations for control of banana weevil. Uganada J. Agric. Sci. 9:908-913.

9. Martin, P. A.; R. F. Schroder; T. J. Poprawski; J. J. Lipa; E. Hausvater and V. Rasocha. 2000. Temperature effects on the susceptibility of the Colorado potato beetle (Coleoptera: Chrysomelidae) to Beauveria bassiana (Balsamo) in Poland, Czech Republic and the United States. J. Entomol. Sci. 35:251-258. 
10. Mueller-Koegler, E. 1965. Piulzkrankheiten bei Insekten. Verlag. Paul Parey. Berlin, Hamburg.

11. Murphy, S.T. and B. R. Briscoe. 1999. The red palm weevil an alien invasive: Biology and prospects for biological control as component of IPM. Biocontrol news and Information, 20 (1):35 - 46.

12. Saleh, M. R. A. 1992. Red palm weevil Olivier is first record in Egypt and indeed in African continent List No. 10634 Africa Collection No.22563. International Institute of Entomology. 56 Queen's Gate, London, Uk.

13. Sewify, G. H. and S. H. Fouad. 2006. Integrated control of red palm weevil Rhynchophorus ferrugineus (Coleoptera: Curculionidae). Agric. Sci. Mansoura Uni., 31(4):2415-2416.

14. Sewify, G. H.; M. H. Belal and S. A. Al-Awash. 2009. Use of the entomopathogenic fungus, Beauveria bassiana for the biological control of the red palm weevil, Rhynchophorus ferrugineus Olivier. Egyptian Journal of Biological Pest Control. 19 (2): 157-163.

15. Thom, C. and K. B Raper. 1945. Amanual of Aspergillus Willamas and Wilkins Co. Batimore, Mol.

16. Yasuda, K.; T. Toyosato and K. Takaesu. 2000. Enhanced infectivity of oil formulation of Beauveria bassiana to Cylas formicarius (Fab) (Coleoptera: Curculionidae). Japanes J. Appl. Entomo. Zool. 44(4): 214-243. 
القدرة المرضية لفطــر البــوفــاريــا باســيانـا علــى ســوســـة النخيل الحمراء (رتبة غمدية الأجنحة - فصيلة السوس) تحث الظروف الحقلية

حسن قاسم بخيت' -محمد عبد السلام على' - ديدير أحمد راغب- عادل عبد الحميد الفيثاوى'

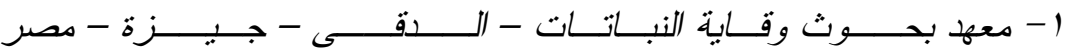

$$
\begin{aligned}
& \text { r- قسم وقاية النبات - كلية الزراعة - جامعة الزقازيق - دصر }
\end{aligned}
$$

تم إنجاز هذا العمل بمنطقة القصاصين- محافظة الإسماعيلية- مصر، لتقييم كفاءة الفطر

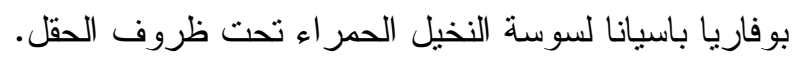

وأظهرت التجارب الحقلية أن حقن الفطر بوفاريا باسيانا أدى إلى حدوث نسبة شفاء فى بـ

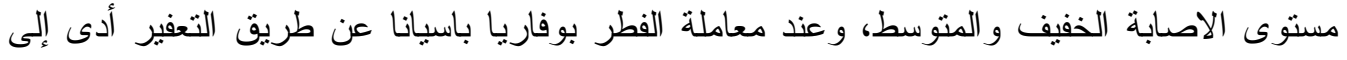
زيادة فى أعداد الحشر ات الكاملة المصابة بالفطر ، وكذا إنخفاض فى أعداد الأثجار المصابة بسوسة بـانة النخيل الحمر اء، ولوحظ عند حقن مبيد الكلورزان و الدايازينون كانا أكثر فعالية على سوسة النخيل 
